\title{
Wind and Solar for Electricity - Experiences in Europe and Germany
}

\author{
H.-J. Wagner", A.J. Daou Pulido \\ Department of Energy Systems and Energy Economics (LEE), Ruhr-Universitat Bochum, Germany
}

Copyright (C) 2015 by authors, all rights reserved. Authors agree that this article remains permanently open access under the terms of the Creative Commons Attribution License 4.0 International License

\begin{abstract}
Over the past decade, the energy landscape in Europe started to change. The main drivers were a significant reduction in $\mathrm{CO}_{2}$ emissions, substitution of fossil for renewable energies and efficiency increase in electricity generation. In this regard, many investments were made in renewable energy generation plants, especially for wind, photovoltaic and biomass applications. This paper highlights the European and especially German electricity market with a focus on the implementation of renewable energies.
\end{abstract}

Keywords $\mathrm{CO}_{2}$ Reduction, Wind and Solar Electricity Generation, Europe, Germany

\section{Introduction}

In the European Union (EU), there is no comprehensive coordination between the EU-States for the further development of the power generation sector. The EU has not defined until now binding goals for the reduction of $\mathrm{CO}_{2}$ emissions as well as for the implementation of renewable energies. However, each EU-State has had its own federal policy and historically has made use of their available domestic renewable and non-renewable energy resources. In general, electricity in Europe is mostly produced using coal, gas and nuclear resources. Renewable generation is different in every single EU-State. Spain, for example, due to their high solar radiation and a high proportion of direct radiation, focusses on the development of concentrating solar power (CSP - solar farm and solar tower power plants). Great Britain instead has made large investments in wind energy on- and offshore. Austria uses due to its topography a large amount of hydroelectric power. In Germany, electricity is mainly generated using coal, gas and nuclear. However, the subsidies for Germany's hard coal mining will end in 2018 and a nuclear phase out will be carried out by the end of 2022. For this reasons, Germany's government undertakes multiple acts to restructure the energy system (so-called "Energiewende") with a special focus on the implementation of wind and solar energies. The objective of this paper is to briefly inform about the most important developments in renewable energy deployment with a focus on solar and wind in Europe and especially in Germany.

\section{Renewable Energy Development in Europe}

Under the Renewable Energy Directive 2009/28/EC, each Member State has to define an individual strategy for the development of renewable energies. Wind energy plays a key role in the EU and it is expected to achieve an installed capacity of about $208 \mathrm{GW}$ by 2020 [1]. Europe had in 2014 the largest installed capacity for wind energy worldwide, followed by China and USA (Table 1). Between 2003 and 2014 the installed capacity for wind energy worldwide had an increase of around 900\% (2003: $40 \mathrm{GW}$; 2014: $370 \mathrm{GW})$ [2, 3]. Germany's wind energy installed capacity had an increase of about $260 \%$ between 2003 (15 $\mathrm{GW})$ and 2014 (40 GW) [2, 3], which makes it the market leader for wind energy in Europe.

In Europe, the promotion of renewable energies has been made through different support schemes. The most important instruments are the Feed-in tariffs (FiTs), feed-in premium (FIPs), tenders, quota obligations - combined with tradable green certificates (TGCs) - or Contracts for Difference (CfDs). Figure 1 shows the support schemes for renewable energies in EU. Other schemes like investment grants, fiscal measures and financing have also been offered. FiTs is the most widely used support scheme in the EU [1]. 
Table 1. Wind energy use worldwide (End 2014) [2, 3]

\begin{tabular}{|c|c|c|}
\hline & Installed Capacity [GW] & Share worldwide [\%] \\
\hline China & 114 & 31 \\
\hline USA & 66 & 18 \\
\hline Germany & 40 & 11 \\
\hline Spain & 23 & 6 \\
\hline India & 23 & 4 \\
\hline United Kingdom & 13 & 2 \\
\hline Italy & 9 & 2 \\
\hline France & 9 & 3 \\
\hline Canada & 10 & 1 \\
\hline Denmark & 5 & $\mathbf{1 0 0}$ \\
\hline Remaining Countries & 58 & $\mathbf{3 7 0}$ \\
\hline Total & & \\
\hline
\end{tabular}

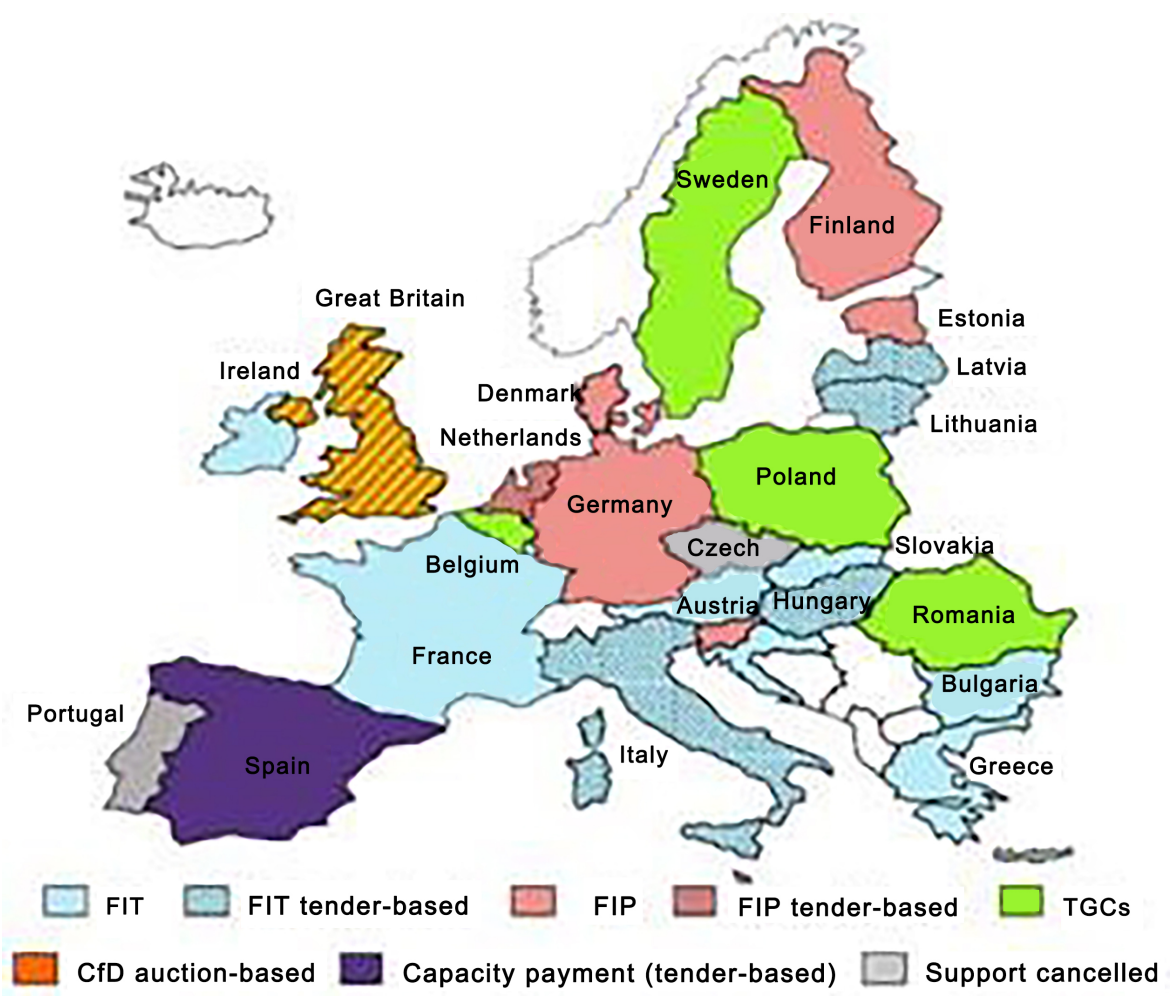

Figure 1. Support schemes for renewable energies in the EU [1]

\section{German Energy System Objectives and Transition}

For the implementation of renewables, the German government started the renewable energy act in 2000, followed by many amendments. In 2010, Germany released targets for $\mathrm{CO}_{2}$ reductions related to the values of 1990 of $40 \%$ until 2020 and $80 \%$ until 2050. Additionally, the goals for implementing renewables for electricity generation were defined: $50 \%$ until 2030 and $80 \%$ until 2050 [4].

Besides biomass, Germany utilizes photovoltaic cells whose installed capacity has been rising in the last years, totaling about $38 \mathrm{GW}$ in 2014. The worldwide installed capacity for photovoltaics was around $200 \mathrm{GW}$ in 2014 [5]. Figure 2 shows the development of the installed capacity of photovoltaic cells in Germany between 2005 and 2014. 


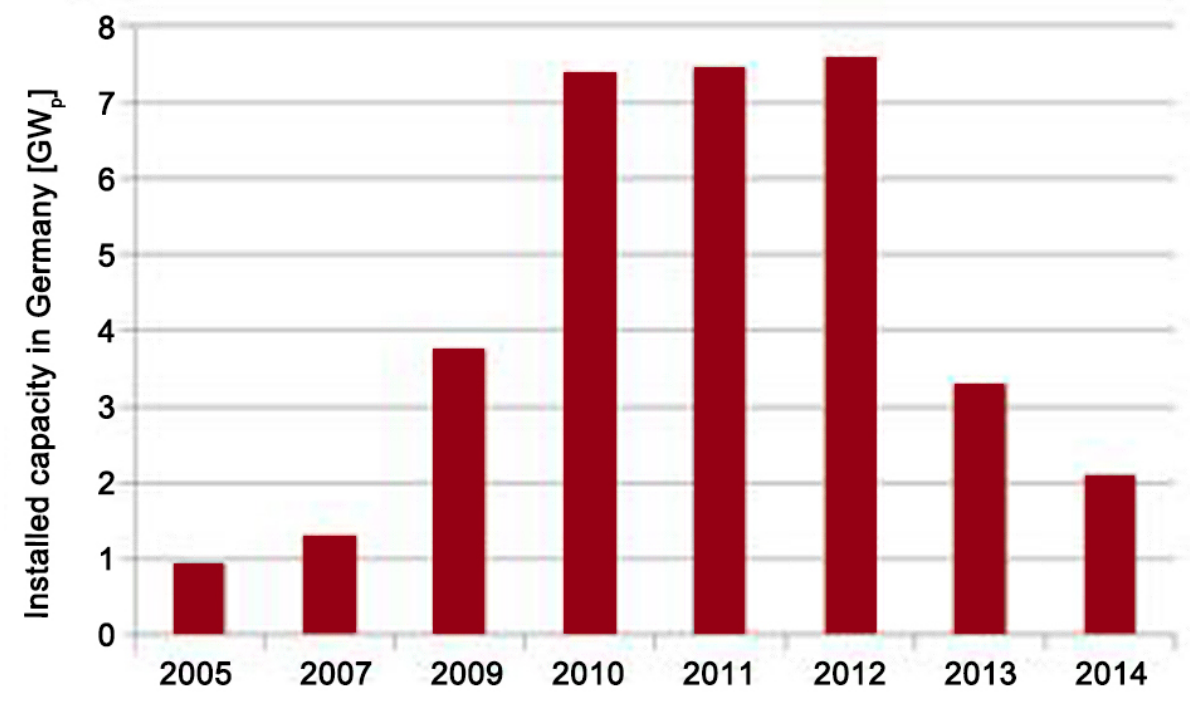

Figure 2. Installed capacity of photovoltaic cells in Germany [5]

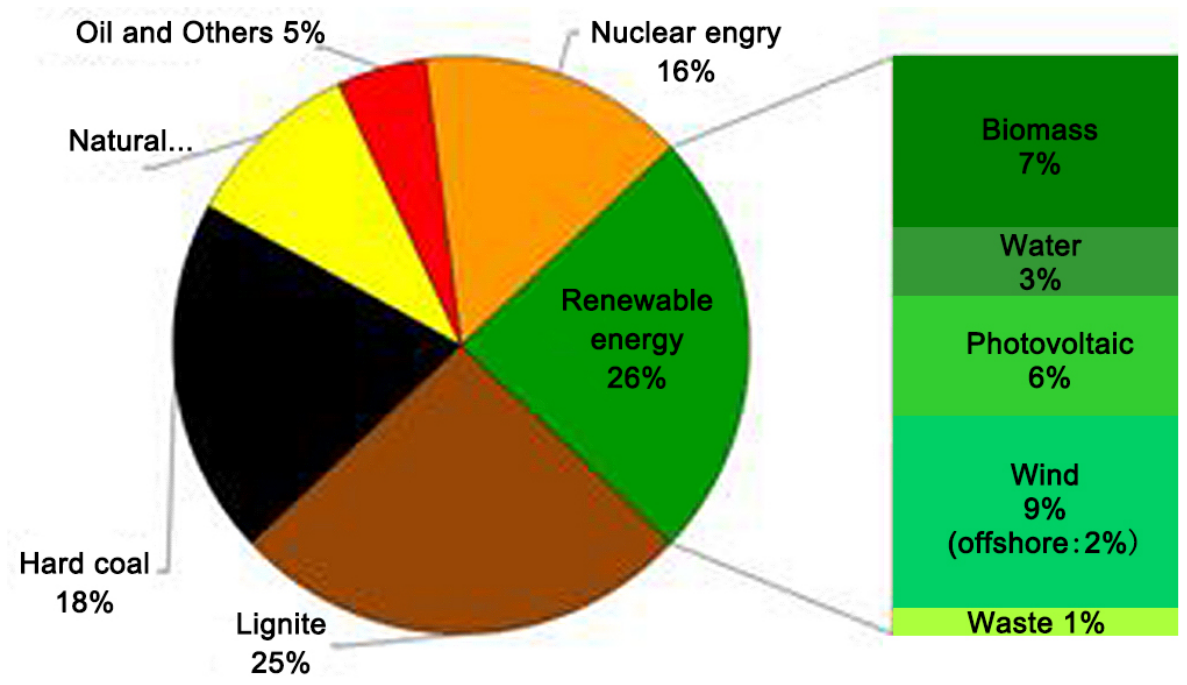

Figure 3. Electricity generation in Germany in 2014 [6]

Due to high wind potential at Germany's coastline, wind energy should play a decisive role. Therefore, Germany's government plans to install around 6,5 GW of offshore wind parks until 2020 and $15 \mathrm{GW}$ until 2030. Due to financing difficulties, not availability of floating cranes and insufficient technical experience, only 2,8 GW of offshore wind converters were installed until mid-2015. In 2014, 4 GW new onshore wind energy converters were installed, totaling an installed capacity for wind energy of about 40 GW.

Renewable energy sources in Germany accounted in 2014 for an all-time record of about $26 \%$ of the electricity generation. The percent share of wind energy in total renewable electricity generation in 2014 was $9 \%$, there of biomass was $7 \%$, photovoltaic cells $6 \%$, hydroelectric power $3 \%$ and municipal waste (also counted as renewable energy) was $1 \%$ [6]. Figure 3 shows the electricity generation in Germany in 2014.

The restructuring of the German energy system has been a success in terms of $\mathrm{CO}_{2}$ reduction and deployment of renewable energies. Between 1990 and 2011, there was a decline in energy-related $\mathrm{CO}_{2}$ emissions of about $24 \%$ [7]. The percent share of renewable energies in the electricity sector has increased from $3,6 \%$ in 1990 to $26 \%$ in 2014 $[6,7]$.

In order to better promote renewable energies, the German government made in 2014 a reform to the "German Renewable Energy Act" ("Erneuerbare-Energien-Gesetz" (EEG)). The reform considered the following aspects [8]:

\section{A. Objectives for green electricity deployment}

1) Year 2025 (2035): 40-45 \% (55-60\%) of the electricity consumption should be covered by green energy sources.

2) Expansion target (wind offshore) until 2020 (2030): $6,5 \mathrm{GW}(15 \mathrm{GW})$.

3) Limiting the expansion of new biogas plants up to 100 MW/year (gross).

4) Limiting the annual expansion of solar and wind 
energy to a maximal amount of 2,5 GW (net).

\section{B. Green electricity commercialization}

1) Direct commercialization of electricity from new plants with a power output of $500 \mathrm{~kW}$ or more.

2) Direct commercialization of electricity from new plants with a power output of $100 \mathrm{~kW}$ or more after 2016 .

C. Reduction of financial support

1) Reduction of excessive promotion and bonuses, progressive support reduction.

2) Funding rates (wind onshore) decreases at profitable locations from $10 \%$ to $20 \%$.

D. Industrial companies

1) Energy-intensive companies have to pay about $15 \%$ of the Renewable Energy Act levy, up to a maximum limit of $4 \%$ of the companies' gross value added.

2) For large scale consumers, such as aluminum or steel plants, the maximum limit decreases to $0,5 \%$.

E. Own power consumption

1) Existing plants are exempted from the Renewable Energy Act until 2016.

2) Electricity generated by eco-electricity plants, is charged with $40 \%$ of the renewable energy levy, other type of power plants have to pay the whole amount.

3) Small plants up to $10 \mathrm{~kW}$ (e.g. photovoltaic systems on house roofs) are exempted from the renewable energy levy.
F. Railways

1) Railway companies have to pay $20 \%$ of the renewable energy levy.

\section{Risk and Experiences}

The transformation of the German energy system will bring positive effects in the long-term, nevertheless the cost are very large [9]. Supporting schemes like the EEG, transmission and distribution grid expansion, research and development in energy-related technologies among others, translate into higher electricity prices for consumers. In Germany, almost $50 \%$ of the electricity price is set by the government through taxes and levies. Figure 4 shows the increase in the renewable energy levy for households in Germany between 2003 and 2015.

In spite of this, public support for the "Energiewende" has remained high in the last years. However, if the costs for the "Energiewende" continue to rise, there could be acceptance problems in society and politics, which could delay further advances in the restructuring of the German energy system. In order to better allocate the cost between the different stakeholders and specially minimize the burden for households, the federal government has reformed the EEG in the year 2014 [9].

On an European level, electricity prices have increased by more than $30 \%$ since 2008 [12]. Figure 5 shows the average electricity prices for households in some European countries in 2013. The lowest electricity prices are found in Bulgaria and the highest prices in Denmark. In average 32\% of the electricity price in Europe is made up of taxes and levies [12].

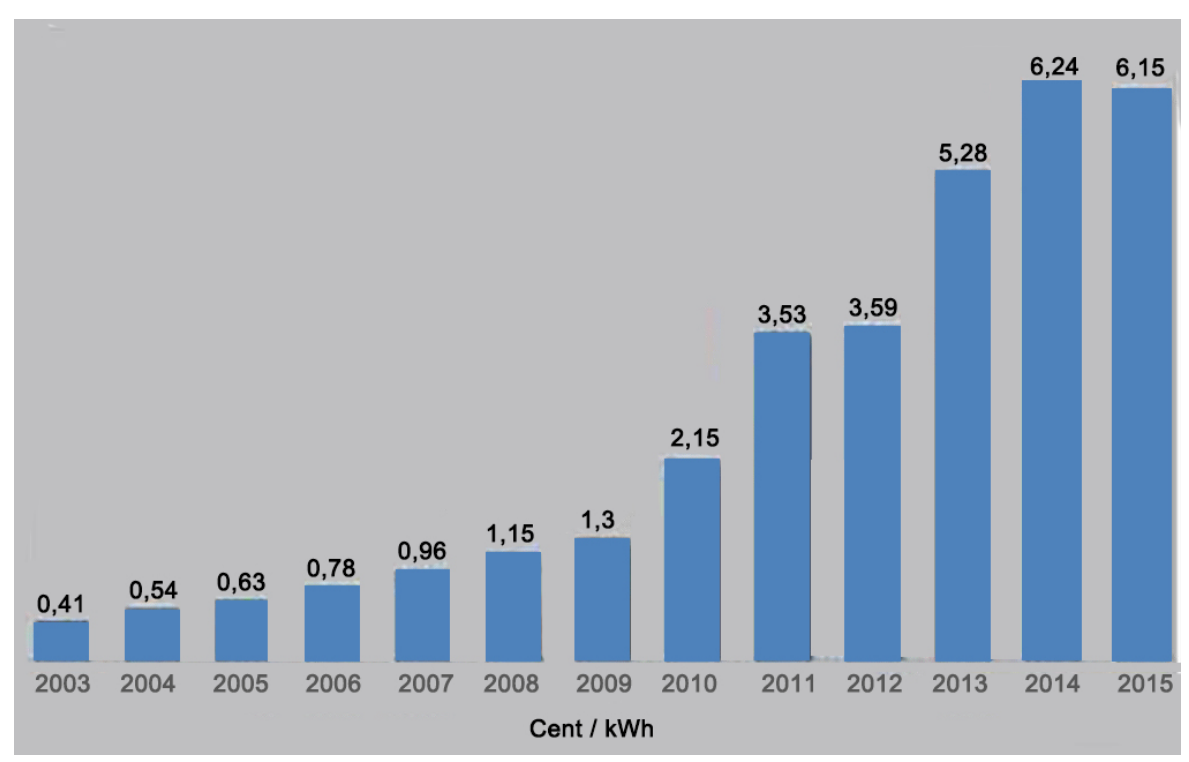

Figure 4. Renewable energy levy for households in Germany $[10,11]$ 


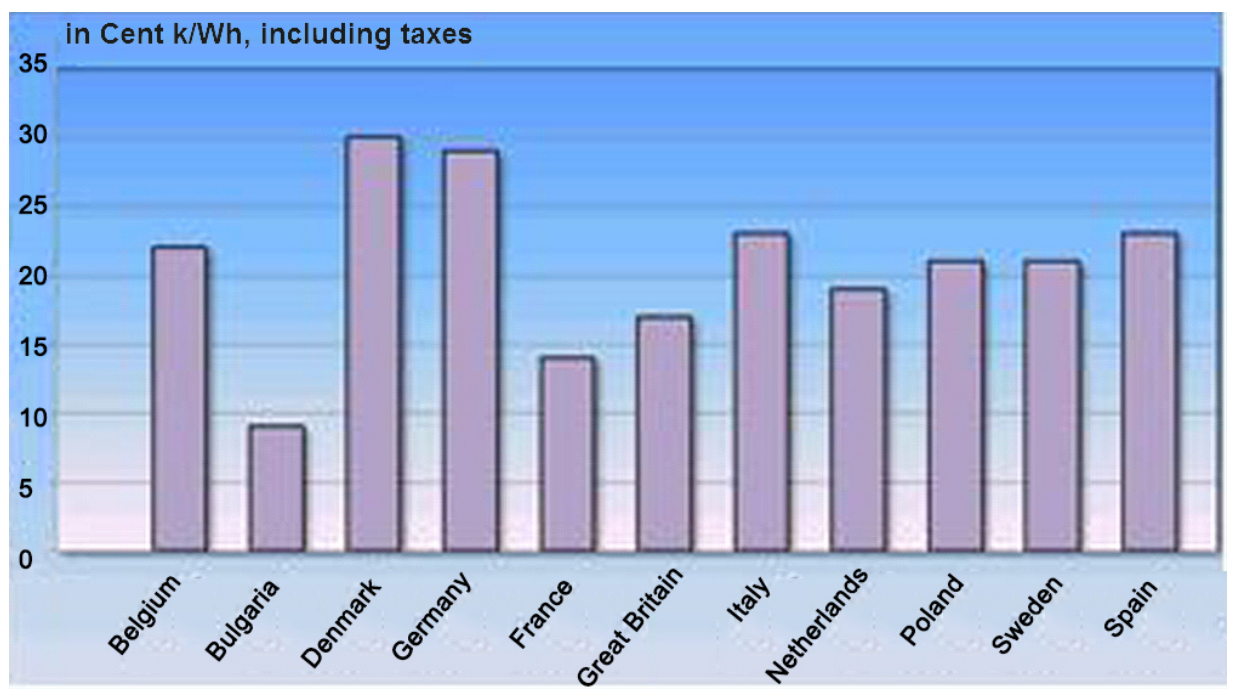

Figure 5. Average electricity prices for households in Europe (2013) [11]

Integration of European electricity markets is important for minimizing electricity costs through higher competition and so gain further public support towards a greener European energy sector. In order to achieve this, it is necessary a coupling of the different support schemes for renewables as well as of the transmission and distribution grids. The expansion of transmission and distribution networks is one of the most important measures for the integration of large amounts of renewable energies. Estimations for Germany show that the transmission network is to be upgraded in the next decade by investing 20-30 billion euros over a length of about $2900 \mathrm{~km}$ and also newly expanded over a distance of about $2800 \mathrm{~km}$. Furthermore, the investments in the distribution networks are in a range between 27.5 to 42.5 billion euros [9].

The "Energiewende" is a huge project whose long-term objectives until 2030 and 2050 could well not be achieved due to unforeseeable societal and political events.

\section{Conclusions}

The high fluctuating power generation by wind and photovoltaic power plants in Germany results in essential additional expansion in the electricity grid - especially in north to south direction, due to the installed wind capacity in the north and the missing capacities of decommissioned nuclear power plants in the south. To keep the high security of electricity supply in Germany, about 2,800 km high voltage grid should be newly build until 2020 - only 270 $\mathrm{km}$ have been realized [13]. Due to the fact that wind and solar energy supply fluctuates, there is a need for energy storages or back up capacity to bridge times where wind and solar resources are not available. Until now the installed capacity of storages is not enough, therefore fossil power plants have to be used as back up. For example the German government foresees the use of available Lignite Power Plants as reserve capacity. In order to develop renewable energies in Europe to its full potential, it is necessary that the EU-States further integrate their energy systems by means of grid expansion and coordinated support schemes.

\section{REFERENCES}

[1] European Commission, 2014 JRC wind status report, Online available from https://setis.ec.europa.eu/publications/jrc-set is-reports/2014-jrc-wind-status-report

[2] DEWI Magazin 2015, Global Installed Capacity \& Forecast, Online available from http://www.dewi.de /dewi res/index.php?id=23\#

[3] Erneuerbare Energien - Das Magazin, Edition March 2015

[4] Bundesministerium für Wirtschaft und Technologie; Bundesministerium für Umwelt, Naturschutz und Reaktorsicherheit, Energiekonzept für eine umweltschonende, zuverlässige und bezahlbare Energieversorgung, BMWi und BMU Öffentlichkeitsarbeit, Berlin, 2010.

[5] Source of the data 01/2015: Bundesnetzagentur/Photovoltaik - Source of the data until 2013: BWK 5/2012

[6] AG Energiebilanzen e.V. , Bruttostromerzeugung in Deutschland in 2014, Online available from http://www.ag-energiebilanzen.de/

[7] AG Energiebilanzen e.V., Bruttostromerzeugung in Deutschland von 1990 bis 2013 nach Energieträgern, Online available from http://www.ag-energiebilanzen.de/

[8] VDI Nachrichten, 4.Juli, 2014, Nr. 27/28, Online available from

http://www.bmwi.de/DE/Themen/Energie/Erneuerbare-Ener gien/eeg-reform.html

[9] International Energy Agency: Energy Policies of IEA Countries - Germany. 2013 Review - Executive Summary and Key Recommendations, Online available from http://www.iea.org/Textbase/npsum/germany2013SUM.pdf

[10] 2003-2014 BMU,EEG/KWK-G, Reuters

[11] Chair of Energy Systems and Energy Economics (LEE), 


\section{Ruhr-Universität Bochum}

[12] Eurostat Database, Online available from http://ec.europa.eu/eurostat/de/data/database
[13] Erneuerbare Energien Das Magazin: Recordzubau 2013 / Netzausbau: Droht 2016 der Engpass?, ISSN: 1436-8773w, Hannover, 01.2014 